\title{
Developing of Learning Material to Create New Processes and Products Learning Material Conventional, Blended Learning and Fully Online at Distance Learning, Open University, Jakarta Indonesia
}

\author{
Afnidar, Hartinawati and Jamaludin \\ Universitas Terbuka \\ Indonesia
}

\begin{abstract}
One of the technologies considered an efficient one is that of blended learning. Blended learning is a potential outcome of advanced technology-based learning system. The charm of blended learning approach lies in the adaptation of technology aided learning methods in addition to the existing traditional based learning. Research and Development $(R \& D)$ is used to describe the activities under taken by distance learning such as learning material to create new processes and products learning material conventional, blended learning and fully online. The term covers activities from scientific research performed in distance learning of the Open university. The contributions of this research to study, in especially education material, at the Open university to testing and refining products before the module of education learning material (case study) given to students. Learning materials play an important role in all courses of higher education. The delivery of course content from the lecture to students especially in open and distance learning higher education institutions like the Open university. This article will explore the use of research and development approach to produce novel learning and instructional materials that can be used to facilitate open and distance learning students. This study is divided into three big steps: 1. Design steps are modification by Borg and Gail, 2. Developing steps is until 8 steps and 3. Evaluation steps is until 15 steps. This article will also describe the process and the result of the study that results in designing a new generation of instructional and learning materials.
\end{abstract}

\section{Introduction}

The Open university has been carrying out the activities of the process of developing learning materials research and development through research. These activities are carried out to improve the quality of learning, UT. During this time, the Open university has provided some facilities to complement its student with academic learning materials and these are print learning materials with non-print and online-based learning process that is an online tutorial. The development of information and communication technology affect learning activities. The existence of the internet access to ease e- learning is increasingly popular in education. An increase in information technology is growing rapidly, allowing students to be able to learn more effectively and efficiently by utilizing internet access as an alternative source of learning.

The use of e-learning based on blended learning and fully online for distance learning was developed in the system of distance education so that learning becomes better, although data indicate that the use of printed materials still remain dominated and became the main teaching material delivery methods in many Distance Education institutions [4].

Research and development in research or Research and Development (R D \&) for Advanced inorganic chemistry courses, developing scripts for the print module delivered to the usual expert teaching at the University. The activities of $R \& D$ are carried out as an attempt of the creation of a new generation of UT module. UT module writing through research $R \& D$ writer in order to develop the module with high creativity so that it can become a quality module is better than ever. However, the technique of writing a module follows the format specified by the UT, as in every module must be theory, landing exercises with answers, summary, and complemented by a formative test answers and reasons are right or wrong. In addition, the modules also need to be equipped with animation, video or tutorial TV. To develop a non-print media, there should be a script on non-print materials first.

Learning materials development activities or the module using the UT research $R \& D$ requirement so that module UT has three courses a which form a module or namely printed learning materials, blended and fully online. In the research of $R \& D$, his step preceded by step searching data through observation and interviews with students. From the results of the interviews with students, it is known that there are some problems experienced by students who take the courses of advanced Inorganic. It turns out that most students have difficulty in understanding the print module. But students who become the participants of the online tutorials are feeling very happy to learn in an online tutorial that is commonly referred to as online tutorials.Online tutorial implemented in 8 sessions per week. The difficulties experienced by the student participants of the online tutorial on Advanced Inorganic subjects 
happens because they have limited time because in general, they are students who are already working. The results of the students' final examinations on this course generally get the values of $\mathrm{C}$ and $\mathrm{B}$ only. There is no student who gets an A.

Other data on the Advanced Inorganic Course (PEKI4417) obtained from UT Computer Center in March 2018 shows that students who had registered Advanced Inorganic subjects were 35 people. Data on the number of students taking the Advanced Inorganic course are students from 17 UPBJJ. The number of students is more than the number of students who take Advanced Inorganic courses during the 2017.1 registration period, which is 32 people. While the number of students who passed the Advanced Inorganic course (PEKI4417) on March 2018 data was 24 people or $75 \%$, with scores ranging from D to B. From these results the researchers felt that the high graduation and grades of these students needed to be increased by striving to develop the Advanced Inorganic course learning material (PEKI4417) through R\&D research to become a new generation of UT learning material.

From the results of interviews with students when searching data about the contents of the Advanced Inorganic course print module, the researchers obtained information that $95 \%$ of students who took Advanced Inorganic subjects were high school teachers. From the interviews, it was found that students felt that the learning material contained in the print module was difficult and too much. In addition, the language description in the Advanced Inorganic course module is also difficult to understand by students who read it. That is why researchers feel the need to develop the Advanced Inorganic course module through $R \& D$ research to become a new generation of UT learning material model that can help students learn.

Other results from the step of gathering information about learning materials and tuton programs from the Inorganic Advanced course is that the subject matter of this course is not similar to the questions in the online tutorial (tuton), because the course material is very difficult and difficult to understand by students. However, students stated that they enjoyed taking tuton and got good grades from tuton tutors even though the UAS scores were small, so most who graduated got B and C. While the tuton value contribution was $30 \%$ of the final grades. However, the tuton value can contribute to the final grade of the student if the student at UAS can answer $30 \%$ correctly.

The results of the development of learning materials using the R\&D method are three kinds of learning materials which include printed, blended and fully online learning materials. The three forms of learning material must be able to be studied independently by students. The development of the three forms of learning materials was also carried out to adapt learning materials to the characteristics of long-distance higher education students. The development of online-based learning materials needs to be done to help students who live in areas far from big cities but still, have internet access. UTbased online learning materials are also expected to help chemical education students living in regional locations who are still having difficulty accessing the internet and it is difficult to come to the UT UPBJJ location. From interviews with students, researchers also received information that students could access the internet because they used internet facilities at the schools where they worked. blended learning is an integrated learning experience that is controlled and guided by the instructor whether in the form of face-to-face communication or his virtual presence. Technological innovation is expanding the range of possible solutions that can be brought to bear on teaching and learning.

We interested in creating more effective learning experiences, increasing access and flexibility, it is likely that our learning systems will provide a blend of face-to-face and computer mediated experiences. Future learning systems will be differentiated not based on whether they blend but rather by how they blend. Like any design problem this challenge is highly context dependent with a practically infinite number of possible solutions.

\section{2. $R$ and $D$}

$\mathrm{R} \& \mathrm{D}$ in education are:

1. A scientific process that identifies needs, develops (creates) educational products and validates these products so that they become new products that are scientific in nature to meet needs.

2. The new product was developed through systematic scientific procedures and field trials so that they meet certain quality criteria or standards, effectiveness, and efficiency.

3. R\&D in education is a combination of basic and applied research to find new models of education products, processes and services. And the model being developed is a physical model of the new generation of UT learning materials to replace the existing modules [6].

The physical model is:

- Replica, like computer simulations (simulators)

- Print learning materials (textbooks, modules)

- Non-printed learning materials (CDs, films)

- Multimedia learning materials (computer-based, web, virtual, online, hybrid learning, blended learning)

- UT's new generation learning materials 


\section{Research Methods}

The development of UT's new generation of learning materials for the Advanced Inorganic course uses the Research and Development (R\&D) method. This research was carried out in 2017. Data collection was carried out through questionnaires and interviews. The number of active students who took the Advanced Inorganic course final examination was 192 people, but the researchers only sent interview requests to $30 \%$ of the 192 students who had complete addresses. Of the $30 \%$ sent by researchers, only 30 people answered and could be interviewed by researchers. The interview details are 12 people can be asked questions via email and 18 people can be interviewed face to face with the researcher.

While the R\&D research method used is the R\&D method combination between Major Steps in The R\&D Cycle [3] with Steps of Systems Approach Model of Educational Research and Development [7] as shown in Figure 1, 2 and 3.

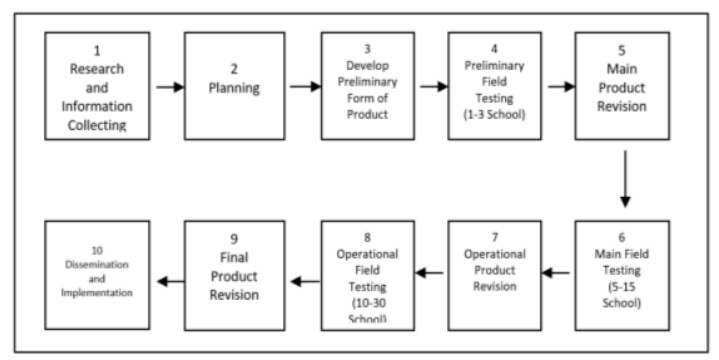

Figure 1. Borg and Gall Model of 1983 for Macro Scale

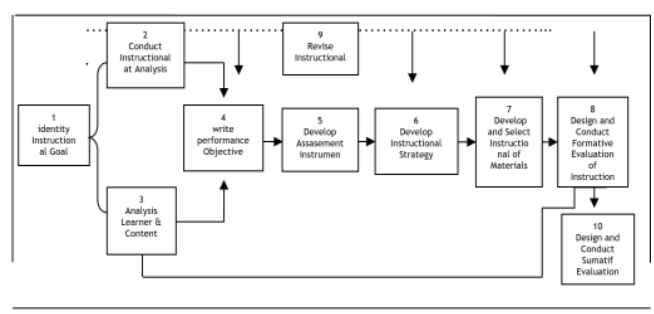

Figure 2. Borg and Gall Model of 2007

Educational research and development (R\&D) are a process used to develop and validate educational products. The steps of this process are usually referred to as the R\&D cycle, which consists of studying research findings related to the product to be developed, developing products based on these findings, field testing in settings where it will be used in the end, and revising it to correct deficiencies found in the field testing phase. The purpose of $R \& D$ research is not to develop products, but to find new knowledge (through basic research). Many research projects involve the development of educational products. Very rarely educational research produces products that are ready to be used operationally in schools or universities. Therefore, researchers as educators have been looking for ways to get learning materials that are ready to be used in schools. This is a form of R\&D contribution to education. From the results of the $R \& D$, the findings produced by basic and applied research use tested products that are ready to be used operationally at school or university. Basic research strategies, and applied in R\&D are needed to bring about changes in education. The steps contained in this model basically have two (2) objectives, namely developing the product and testing the effectiveness of the product to achieve the planned goals.

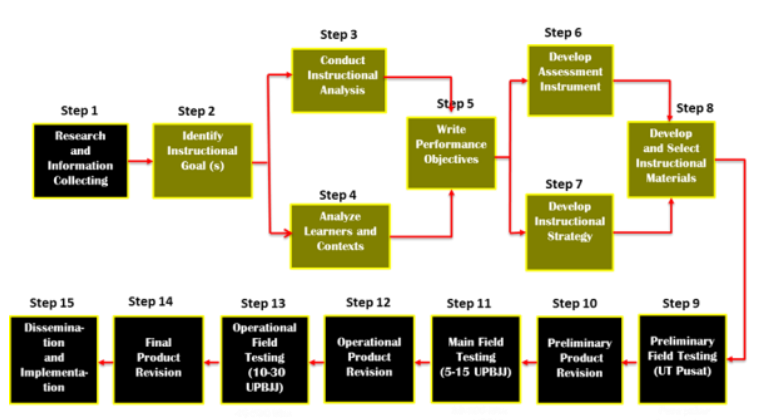

Figure 3. Models of UT 2017 New Generation Learning and Development Materials [6]

The following is a description of the development of printed model teaching materials, blendedlearning and fully online using Research \& Development (R\&D) methods.

There are 15 steps in the research model and the development of UT's new generation of learning materials, but the discussion is limited to steps 1 through 8.

Model development must be carried out through a (scientific) research process, involving systematic development steps and a validation/evaluation/field trial process (followed by revisions) until validity, effectiveness and efficiency are tested. The model produced through the scientific process is a scientific product.

\subsection{The research and development (Research and Development) steps are:}

\section{STEP 1: Research and information gathering}

Research and collection of information about learning materials and tuton programs that have been carried out. Research on advanced Inorganic chemistry tuton, the problem is that the UAS problem is admittedly not similar to the problems in 
tuton, because the module is very heavy and difficult to understand. Students like to follow tuton and get good grades but in UAS the score is small, so most graduates get $\mathrm{C}$. While the final grade will only be worth it if students at UAS answer 30\% correctly then the tuton value is recognized by $30 \%$ to get the final score.

\section{STEP 2: Identifying the instructional Goal (s)}

Identify instructional objectives and compare the Instructional Goals of the old module with the new generation learning material modules (BP Geru). The conclusions of new modules by modifying the modules no longer consist of some $\mathrm{Kb} 1$ to 4 , but it is simpler just one and more accurate.

STEP 3: Conduct Instructional Analysis (Conducting Instructional Analysis)

Instructional strategies pertain to approaches in managing comprehensive instructional content and processes to reach one or a group of instructional objectives. It integrates various components which include the sequence of learning activities, outline of contents, methods, media \& tools, and learning time (in minutes) [6]. This arrangement has undergone several changes, because, at the time of the actual making of the module, there were many recent things that were not known before and had not been thought about such as entering the PEKI4417 video section that has 7 episodes on Youtube, and PhET Colorado, so that it became more complete.

STEP 4: Analyze learning and Contexts (Analyze students) analyze (learners) and context (contexts).

Analysis of students produces a description of the characteristics of students related to their learning abilities as UT students. Context analysis produces a description of the availability of learning facilities and infrastructure available to students if it is linked to the ideal needs to follow the learning system at UT. There are locations that vary from climate and place in Indonesia, where the physical condition of the region and the population of Indonesia has a very high level of complexity, in terms of its natural state. Indonesia's varying natural conditions lead to population conditions that vary in social conditions. Where various variants of social conditions and life within them, can still run harmoniously (Bhineka Tunggal Ika) in the Unitary State of the Republic of Indonesia. This is very much recognized by the Open University, which already has a Distance Learning Program Unit (UPBJJ) 40 including abroad. And a regional category will be chosen that represents this climate by providing 3 types of learning material models, namely conventional, blended and fully online. The next year will be piloted in the example of the UPBJJ region (Distance Learning Program Unit) which represents the nature of climate and students and the category of facilities and infrastructure. And it will experience repeated revisions.

STEP 5: Write Performance Objective (Writing Performance Objectives)

Performance goals or specific learning objectives that contain the performance expected from students at the end of learning. Basically, the list of performance goals are obtained from each subcompetency listed in the final learning outcomes. The usual Performance Goals are also called Special Learning Objectives (instructional objectives). The existence of sub-competencies are a general elaboration and competency that has been agreed between researchers and several authors, so that general instructional objectives can be achieved.

$\begin{array}{lccc}\text { STEP 6: } & \text { Develop } & \text { Assessment } & \text { Instrument } \\ \text { (Developing } & \text { learning } & \text { outcome } & \text { assessment } \\ \text { instruments) } & & & \end{array}$

Developing assessment instruments to be used in measuring student learning outcomes. Competencies that have been specified in special Instructional Objectives (ICT) using assessment tools. Preparation of module 1 to 6 questions grid has been completed and the creation of two social sets in an objective form had been prepared which students will try out next year whether the module that has been written as a trial is around $30 \%$ or 3 modules, can be received or revised repeatedly. In accordance with the learning model agreed upon in 2017.

\section{STEP 7: Develop Instructional Strategy (Learning} Blue Print Strategy

The seventh step is to develop instructional strategies for inorganic chemistry courses 3 which are suitable for the instructional objectives of the course. Each instructional strategy is directed toward achieving one or one instructional goal group. Like a part that is very difficult to understand it does not have to be printed and can be transformed into a CD where the contents are a direct explanation from the module author expert.

\section{STEP 8: Develop and select instructional materials}

\section{Theoretical framework:}

In the process of developing the material in each module, writing signs had been made so that they can lead to general competence through specific competencies and learning strategies that are 
expected to have the process and stages of writing modules already in place.

According to De Cadiz and Aguirre [5], a typical module consists of the following components:

1. Title. It should be brief, comprehensive and interesting.

2. Target Population. This specifies the level and the kind of students to which the module is directed.

3. Overview. A bird's eye view of the topic to be covered by the module. This is needed to prepare the mental set-up and to motivate the students.

4. Objectives. These would guide the students what exactly are expected of them in going through the modules in terms of learning objectives.

5. Instructions to the Learners. Instructions should be worded with clarity, brevity, simplicity and specificity to enable the students to carry out the suggested activities, to answer specific questions, to accomplish sheet assignment, and other related activities by themselves.

6. Entry Behavior and Prerequisite Skills. The entry behaviour and prerequisite skills are needed to make the learners use the module successfully. It provides them preliminary assessment whether the module is within their capabilities or not. If they feel they do not have the prerequisite skills, they may skip the module and instead concentrate on the development of such requirements before they try it.

7. Pre-test. The pre-test is given to determine how much the learners already know about the topic. If the results show that they have considerably mastered it, they may be given the next module.

8. Pre-test Feedback and Evaluation. A key to correction must be provided within the module for the students to determine whether their answers to every item in the pre-test are correct. The total number of correct items must be given an equivalent grade to find out whether the learners pass or fail the test given. Such an equivalent grade is contained in the pre-test evaluation.

9. Learning Activities. This is the heart of the module which specifies the different activities that the students must undertake in order to achieve the specific learning objectives. Such activities include various lessons, study sheet assignments, tests, and even suggested projects.

10. Post-test. The post-test is taken after all the students have done all the learning activities suggested in the module. This is to find out how far they have learned from the module. The pre-test may be given as post-test in the absence of other equally well-prepared post-test.

11. Post-test Feedback and Evaluation. The post-test feedback serves as the key to correction while the post-test evaluation provides the grade equivalents of the different scores obtained by the students.
12. Teacher's Manual or Guide. To ensure effective use of the manual, the teacher needs the necessary pointers, helpful alternatives, and necessary background to strengthen mastery of topic. It is necessary that the teacher's manual or guide can clarify things, provide cautions in the use of the manual, call the attention of the teacher to emphasize salient points, and suggest enrichment activities to maximize students' learning

Note 7 to 12 is the same as the model agreed upon by the new UT 2017 teaching material writing team. Steps number 9 to 15 in $R \& D$ research will be carried out in the following year.

\section{Expected Outcomes}

In this Advanced Inorganic R\&D research, it is expected to produce products:

1. Printed teaching materials

2. Blended learning teaching materials

3. The instructional material is fully online

The differences in Learning Materials for Conventional, Blended and Fully Online Models at Distance Learning according to Pannen [12] are outlined in Table 1 .

Table 1. Differences in Learning Materials

\begin{tabular}{|l|l|l|}
\hline $\begin{array}{c}\text { Proporsi } \\
\text { Online }\end{array}$ & Deskripsi & Tipe \\
\hline $0 \%$ & $\begin{array}{l}\text { Tatap muka sepenuhnya, pembelajaran dengan } \\
\text { bahan ajar cetak atau lisan }\end{array}$ & $\begin{array}{l}\text { Tatap muka } \\
\text { tradisional }\end{array}$ \\
\hline $1 \%-29 \%$ & $\begin{array}{l}\text { Menggunakan teknologi Internet untuk } \\
\text { memfasilitasi pola tatap muka, mungkin } \\
\text { menggunakan LMS atau situs web untuk mem-pos- } \\
\text { kan bahan ajar dan tugas }\end{array}$ & $\begin{array}{l}\text { Web-enhanced } \\
\text { (pembelajaran } \\
\text { diperkaya dengan } \\
\text { akses Internet) }\end{array}$ \\
\hline $30 \%-79 \%$ & $\begin{array}{l}\text { Mengkombinasikan cara online dan tatap muka. Ada } \\
\text { proporsi pengantaran bahan ajar yang online, } \\
\text { biasanya dilengkapi dengan diskusi online, dan ada } \\
\text { pengurangan frekuensi tatap muka }\end{array}$ & $\begin{array}{l}\text { Blended/Hybrid } \\
\text { (e-learning) }\end{array}$ \\
\hline$>80 \%$ & $\begin{array}{l}\text { Sebagian besar atau seluruh bahan ajar diantarkan } \\
\text { secara online, bisa tanpa porsi tatap muka sama } \\
\text { sekali }\end{array}$ & $\begin{array}{l}\text { Fully Online } \\
\text { (e-learning) }\end{array}$ \\
\hline
\end{tabular}

Several other experts provide a description of the differences in the Conventional, Blended and Fully Teaching Materials for Online Learning in Distance Learning as follows.

\section{Conventional Model}

In general, teaching materials can be divided into printed and non-printed teaching materials. Print teaching materials can be in the form of handouts, books, modules, brochures, and student worksheets. While nonprinting teaching materials include audio teaching materials such as cassettes, radios, LPs and audio compact discs. Audio visual teaching materials such as, CAI (Computer Assisted Instruction), and web-based teaching materials (web-based learning 
materials) [10]. The instructional materials referred to as printed teaching materials are textbooks. This is because, textbooks are closely related to the curriculum, syllabus, competency standards, and basic competencies. This text / printed category teaching material is limited to less than $30 \%$ online. Blended $>30 \%$ to $80 \%$ and $>80 \%$ are fully online.

According to Mursell and Nasution [11], conventional or traditional ways of teaching such as learning materials are shared and students are assigned to make learners learn in ways that are very inefficient, students are unable to read with a specific purpose, are unable assess what is learned, unable to use mathematical or scientific techniques, unable to compile facts and draw conclusions, because they do not obtain authentic learning outcomes. In addition, according to Rachman (2006: 32), it is not uncommon to find teaching staff who impose their will. Children are forced to work, to learn or to achieve certain target values. The attitude of the teaching staff like this not only makes the child become depressed but also will make the child think that learning is an obligation, not a necessity. This kind of situation is actually realized by every educator, that in the teaching and learning process, there are always students who have learning difficulties and difficulties in adapting. These students need special handling in overcoming their learning difficulties, such as through tutoring and can also be done by educators by making improvements to learning methods that they have carried out or integrated with other methods without eliminating the old methods. https://putuwidyanto.wordpress.com/2011/01/14/ conventional learning / cited 15 Oct 2018.

The survival of tertiary education institutions in the 21 st century will increasingly rely on various forms of electronic delivery and communication inside a marketplace that requires education to be flexible. e-learning is now widely used in most of the developed countries to promote distance education (DE) and life-long learning in an effective way.

\section{Blended learning}

Blended learning has several definitions, but generally, blended learning is known as learning that combines online learning with face-to-face learning [1], [9], [16]. Online discussion is an important component of blended learning. Sharing ideas and responding to peer questions and receiving feedback from teachers play a positive role in learning success. More effective online discussion is a marker of the efficiency of the implementation of blended learning explain that extended learning describes the setting of face-to-face meetings that are characterized by direct interaction between humans and the regulation of information and technology (ICT) that occur indirectly. Through blended learning, students can still do online learning outside the classroom. According to Rovai and Jordan [15] the blended learning model is a combination of excellence in learning that is done face-to-face and virtual learning.

\section{Fully online}

Technological advances allow the teaching and learning process not to be done directly face to face, have the opportunity to teach online. Only with an internet connection, students can get all the information they need until they are able to understand the concept well. Learning activities that are carried out individually make students to be able to adjust to their own abilities.

Online teaching typically refers to courses that are delivered completely online, meaning there are no physical or on-campus class sessions. Online courses can be designed for a handful of enrolled students or can be made open and accessible to a wide variety of participants, such as with a MOOC.

\subsection{Steps to Develop Early Forms of Second Year UT New Generation Teaching Materials}

The development phase of the initial form of the modified product, in this phase, the researcher modified the previous module made by the previous conventional model. The purpose of this modification is to match the learning environment for learning activities and to achieve the planned learning objectives. At this stage, researchers and expert teams compile the material that will be used in learning activities. The purpose of this phase is to find out the type of material that must be mastered by students so that they can achieve the desired learning objectives. The material presented must lure students, especially those who take Advanced Inorganic course material so that students will understand the lesson in a complete and easy way. In the development of this material, it can be done by conducting meetings and discussions through group discussion forums with a team of conventional lecturers who also deliver the same courses at the University. In the Pre-production phase, researchers met and discussed with the material experts and ICT experts to create a learning video complementing the print module.

Before conducting the e-learning/video media production that will be used to complete UT's new generation of teaching materials for the Advanced Inorganic course, the researcher discusses the video content design with the material experts and ICT experts to produce a video script that matches the printed teaching material. In this case, the video must also be developed because it is part of the Advanced 
Inorganic course printed teaching material. Video material is a printed teaching material that requires a more detailed explanation from the expert who is also the author of the module. Web design experts are also needed by researchers because web design experts must help researchers develop three forms of teaching materials (printed, blended and fully online). Data search activities were carried out in the first year of R\&D research for Advanced Inorganic subjects. Whereas in the second year, researchers must develop teaching materials into three forms of teaching materials. And in the third year, researchers must test teaching materials to a number of UPBJJUT.

Trials on e-learning design are carried out as a standard to see how far the teaching materials can be understood by students or their users. The trial was carried out by experts both in the material and media related to the material to be submitted and developed.

The obstacles faced by researchers in developing teaching materials with R\&D methods are experts who must write modules and develop their videos with limited time. Experts or authors of Advanced Inorganic course materials are lecturers from the Department of Chemical Education in UNJ Jakarta, Atmajaya Jakarta and UGM Jogyakarta.

The results of the study are:

1. There is a change from the preparation of general and specific instructional objectives for each teaching material module

2. There is a change in the learning strategy to be adjusted to achieve its instructional objectives

3. There are lattice and items from each module in accordance with the instructional objectives

4. There is a learning video for each module

The development of modules with a combination of media has been developed, it is expected that the lecturer will mark things as described below:

- Lecturers are not the only source of learning. The role of the lecturer is to become a facilitator that will influence students to take part in the learning activities that have been made. Lecturers need to make learning materials and strategies that can attract students' learning interest and motivation and stimulate student learning activity.

- Variations in learning activities that are made using certain media and instructional designs are considered as an effort to maximize learning resources in order to attract students' interest in learning;

- The use of blended learning models must be accompanied by material and lesson plans that have been developed by the lecturer. With the supporting set, it will be easier for the lecturer to deliver the learning material.

Challenges on open distance learning are the modern distance learner will have to learn how to use ICT and that ICT is not taught in many places (and where it is taught it is relatively expensive) and also there are other problems in developing countries including unstable internet.

\section{References}

[1] Akkoyunlu, Soylu Y., (2008). "A Study of Student's Perceptions in a BlendedLearning Environment Based on Different Learning Styles". International Forum ofEducational Technology\& Society. Vol. 11, No. 1, p. 183-193.

[2] Benny Agus P. dan Dewi Patmo P., (2005). Ragam Media Dalam Pembelajaran. Jakarta: PAUPPAI, Universitas Terbuka.

[3] Borg, W.R. \& Gall, M.D., (1983). Educational Research: An Introduction, Fifth Edition. New York: Longman.

[4] Brigham dalam Belawati, T., (1999). Perkembangan Pemikiran tentang pendidikan Terbuka dan Jarak Jauh.

[5] De Cadiz, G., Aguirre, Jr, D., (2013). Instructional Materials Development Manual. 10.13140/2.1.1744.0001. https://www.researchgate. net/publication/266023994

[6] Forum Pertemuan Akademik Dosen FKIP Universitas Terbuka, oleh Atwi Suparman 09 November 2016.

[7] Gall, M. D., Gall, J. P., \& Borg, W. R., (2003). Educational Research, An Introduction (Seventh Ed). Boston: Allyn and Bacon.

[8] Gall, J. \& Borg, W.R., (2007). Steps of Systems Aproach Model of Educational Research and Development.

[9] Garrison, D. R., \& Vaughan, N., (2008). Blended Learning in Higher Education. San Francisco: Jossey-Bass.

[10] Ika Lestari, (2013). Pengembangan Bahan Ajar Berbasis Kompetensi. Padang: Akademia Permata.

[11] Mursell, J dan Nasution, S., (2006). Mengajar dengan Sukses. Jakarta: Bumi Aksara.

[12] Pannen, Paulina dan Purwanto, (2001). Penulisan Bahan Ajar. Jakarta: Pusat antar Universitas untuk Peningkatan dan Pengembangan Aktivitas Intruktional Ditjen Dikti Diknas.

[13] Pendidikan jarak jauh adalah proses belajar mengajar yang dilakukan secara jarak jauh melalui 
penggunaan berbagai media komunikasi (Permendikbud No. 109/2013)

[14] http://kopertis3.or.id/v2/wp-content/uploads/ Paulina-Pannen-Kebijakan-PJJ-dan-E-Learning.pdf

[15] Rovai, A.P., Jordan, H.M., (2004). Blended learning and sense of community: A comparative analysis with traditional and fully online graduate courses, International Review of Research in Open and Distance Learning,Vol. 5, Number 2, 14923831, Research in Open and Distance Learning, Vol. 5, Number 2, 1492-3831, diunduh 25 Agustus 2011.

[16] Garrison, D., \& Kanuka, H., (2004). Blended Learning: Uncovering Its Transformative Potential in Higher Education. The Internet and Higher Education. 7. 95-105. 10.1016/j.iheduc.2004.02.001. 